Реалізувати соціальне замовлення суспільства має найновіша безрозрахункова методика конструювання швейних виробів.

Використання запропонованої методики конструювання жіночих плечових виробів у процесі професійної проектно-конструкторської підготовки майбутніх фахівців швейної галузі під час проектування i виготовлення одягу сприяло підвищенню інтересу до занять, рівня оволодіння конструкторськими знаннями i вміннями, якісному та швидкому виготовленню виробів.

Розвиток комп'ютерної техніки наприкінці XX століття сприяв переходу від традиційних ручних методів проектування до нових комп'ютерних систем розроблення нових моделей одягу. Використання найновіших технологій, зокрема комп'ютерних, у галузі інженерії має перевести професійну діяльність фахівця швейної галузі на новий, більш високий якісний рівень.

Задля підвищення якості виконання проектних робіт, перспективним постає поява доступних вітчизняних систем автоматизованого проектування одягу. Упровадження САПРО в навчально-виробничий процес професійної підготовки майбутніх фахівців швейної галузі у професійно-технічних навчальних закладах, коледжах та вищих навчальних закладах дозволить підготувати сучасного працівника «нового типу».

Розроблена нами методика конструювання жіночого плечового одягу має широкі можливості іiі застосування фахівцями швейної галузі під час проектування одягу. Застосування комп'ютерної програми методики конструювання дозволяє отримати креслення основи виробу в автоматизованому режимі.

\title{
Література
}

1. Васенок Т. М. Конструювання 3 елементами моделювання плечового виробу [методичні рекомендації]. 8 клас / Тетяна Михайлівна Васенок. - Глухів : РВВ ГДПІ, 1999. - 72 с. 2. Васенок Т. М. Основи конструювання жіночого одягу: [навч. посіб.] / Тетяна Михайлівна Васенок. - Глухів : РВВ ГДПУ, 2005. - 100 с. 3. Гриценок І. А. Педагогічні умови організації виробничого навчання учнів ПТНЗ швейного профілю: дис. ... канд. пед. наук: 13.00.04 / Гриценок Інна Анатоліївна. - К., 2007. - 305 с. 4. Изделия швейные, трикотажные, меховые. Типовые фигуры женщин. Размерные признаки для проектирования одежды: ОСТ 17-326 - 81. - М. : ЦНИИИТЭИлегпром, 1981. - 109 с. 5. Сушан А. Т. Інженерне проектування швейних виробів: [навч. посіб.] / Алла Тимофіївна Сушан. - К. : Арістей, 2008. - 172 с.

УДК 370.98.23

Надія Вовк

\section{ОСОБЛИВОСТІ СТРУКТУРНИХ ЕЛЕМЕНТІВ ФОРМУВАННЯ СПОЖИВЧОЇ КУЛЬТУРИ МАЙБУТНІХ УЧИТЕЛІВ ТЕХНОЛОГІЇ}

Вовк Н. В. Особливості структурних елементів формування споживчої культури майбутніх учителів технології.

У статті подано аналіз концепту «споживання», досліджено генезу поняття «споживча культура», «культура споживання», визначено складники споживчої культури. Культура споживання майбутнього вчителя має динамічний характер, розвиток здійснюється на основі задоволення потреб у професійній діяльності, культурі, особистісних цінностях. Споживча культура надає набори зразків споживання, виборів, цінностей і смаків, які допомагають людині орієнтуватися в соціальному просторі та отримати якісну освіту. 
Ключові слова: структурні елементи, споживання, культура споживання, споживча культура, професійна діяльність учителя, майбутні вчителі технології.

Вовк Н. В. Особенности структурных элементов формирования потребительской культуры будущих учителей технологии.

В статье представлен анализ концепта «потребление», исследована сущность понятия «потребительская культура», «культура потребления», определены составные элементы потребительской культуры. Культура потребления будущего учителя имеет динамический характер, развитие которого осуществляется на базе удовлетворения нужд в профессиональной деятельности, культуре, личностных ценностях. Потребительская культура дает примеры образцов потребления, выборов, ценностей и вкусов, которые помогают человеку ориентироваться в социальном пространстве и получить качественное образование.

Ключевые слова: структурные элементы, потребление, культура потребления, потребительская культура, профессиональная деятельность учителя, будущие учителя технологии.

Vovk N. V. The features of the structural elements of consumer culture forming of the future teachers of technology.

The concept of the analysis of «consumption» is presented in the article as well as the essence of the concept «consumer culture», «culture of consumption» is analysed, components of the consumer culture are defined. The culture of consumption of the future teacher has dynamic development that is carried out on the basis of satisfaction of needs in professional activity, culture, personal values. The consumer's culture gives examples of models of consumption, elections, values and tastes which help the person to be guided in the social space and to get a high quality education.

Key words: structural elements, consumptions, culture of consumption, consumer's culture, professional activity of teacher, future teacher of technology.

У сучасному суспільстві, де активно розвивається соціально зорієнтована економіка, пріоритетними постають проблеми споживання і споживацької поведінки. Споживання починає відігравати основну роль у процесі відтворення, підпорядковуючи інші його складники - виробництво, розподіл, обмін; виходить за межі економічної галузі, що виявляється у всіх соціокультурних практиках. Активним агентом конструювання $є$ суспільство, яке формує споживацькі орієнтації і задає визначені споживацькі стандарти. Поширення масової споживацької культури супроводжується ствердженням визначеного набору цінностей: культу насолоди, комфорту, статку. Сучасне суспільство споживання сприяє тому, що молодь стає залежною від моди, брендів, новинок, які з'являються на ринку, що, у свою чергу, призводить до формування пасивної, некритичної споживацької поведінки молодих людей. Актуальність окресленої проблеми полягає в тому, що в умовах глобального поширення масової культури, ключовими цінностями якої постають розваги та споживання, необхідно формувати у студентів соціально значущі цінності, знання, норми і зразки поведінки, розумне поєднання у споживачі матеріального і духовного, що має стати цілеспрямованим і систематичним педагогічним процесом.

Проблеми споживання і споживацької поведінки є об'єктом вивчення відносно нової галузі соціологічного знання - соціології споживання. Провідними науковцями, які розглядають споживання з позиції соціології, є Л. Волочкова, О. Гофман, В. Ільїн, 
В. Козловський, Н. Лисиця, В. Мініна, В. Пилипенко, В. Радаєв, Я. Рощина, Е. Суіменко, В. Тарасенко та ін.

До становлення соціології споживання як самостійної галузі основними темами досліджень споживання були: соціальна нерівність, соціальна стратифікація (Т. Веблен, М. Вебер, П. Бурдьє, В. Зомбарт), масова культура (Г. Маркузе), суспільство достатку (Дж. Гелбрейт, Д. Белл).

Mema cmammi: здійснити аналіз концепту «споживання», дослідити генезу понять «споживча культура», «культура споживання», визначити складники споживчої культури.

Концепт «споживання» узагальнює багато положень, властивих соціологічним теоріям споживання, він $є$ певним початком, що постає носієм різноманітних форм майбутньої організації, полем перетину форм шляхів розвитку суспільства, відносин між людьми.

Говорячи про споживання, наголошуємо, що термін і саме поняття виникло в межах економічної науки, яка розглядає процес споживання товарів у взаємозв'язку 3 ïx виробництвом. Споживання як економічна категорія має свою специфіку аналізу, пов'язану $з$ розумінням цього явища як вияву економічного інтересу, що, у свою чергу, слугує вихідним мотивом до здійснення процесу виробництва.

Відзначаємо, що варто розрізняти поняття «культура споживання» i «споживацька культура». Якщо перше характеризує індивідуальний досвід людської поведінки у сфері придбання й використання товарів, то друге поняття стосується функціонування культури сучасного суспільства, «у якій індивідуальні смаки відбивають не тільки соціальні характеристики (вік, стать, зайнятість тощо), але й соціальні потреби, а також способи життя споживачів» [1, с. 355]. Поряд 3 такими поняттями, як «масова культура», «суспільство споживання», «інформаційна епоха» тощо, споживацька культура $є$ однією з характеристик суспільства постмодерну.

Нас насамперед цікавить культура споживання як сукупність поведінкових характеристик індивідів, пов'язаних із придбанням i використанням продуктів, зокрема продуктів освіти. Поняття «культура споживання» відбиває взаємопроникнення споживання і культури як відносно самостійних сфер людської діяльності. У найбільш загальному вигляді під культурою споживання розуміємо комплекс цінностей, ідей, поглядів, традицій та інших символів, за допомогою яких люди спілкуються й оцінюють один одного, і які виражені в типах та формах організації життя людей, у взаєминах між ними, у створюваних духовних i матеріальних цінностях із позиції виникнення й задоволення відповідних потреб [4].

Культура споживання тісно пов'язана зі світом повсякденності індивіда. Вона формується і функціонує в межах повсякденної взаємодії людей, тому що є продуктом вираження повсякденних форм поведінки. Культура споживання майбутнього вчителя становить надіндивідуальну реальність, яка створюється людьми як безпосередньо, так і за допомогою соціальних інститутів - держави, бізнесу, навчання тощо. Гармонізація естетичних, пізнавальних i моральних потреб- необхідна умова формування споживчої культури особистості майбутнього вчителя.

На наш погляд, провідне значення має культура споживання, оскільки саме в культурі знаходить своє вираження світ повсякденності. Звичні форми поведінки засвоюються індивідами у процесі навчання, а самі ці форми склалися в діяльності попередніх поколінь, тобто у процесі культурного становлення того чи того суспільства. Людина споживає щодня, тому споживацька поведінка є складником повсякденного світу, а споживані речі можуть бути представлені як об'єктивація 
життєвих практик.

Культура споживання охоплює такі елементи [3]:

- споживацькі цінності - переконання індивідів щодо способу, стилю життя, формальні і неформальні правила поведінки, що визначають характер споживання продуктів;

- споживацькі норми - правила, зразки поведінки, що поділяються членами певного співтовариства, і регулятивні принципи поведінки людей у процесі ухвалення рішення;

- споживацькі звичаї і традиції- історично укладені схеми споживацької поведінки, що передаються 3 покоління в покоління, пов'язані з загальною культурою певного суспільства;

- споживацькі стереотипи - типові, стандартні сценарії, що описують схеми психологічного сприйняття явищ, подій, пов'язаних із вибором, - це міжгруповий механізм соціального впливу, що дозволяє швидко, просто й надійно категоризувати соціальне оточення індивіда.

Джерелами споживчої культури є: накопичення і трансляція від покоління до покоління знань, зразків, норм, цінностей поряд із внутрішніми інноваціями (слідування моді, зміна стилю життя) і зовнішніми запозиченнями (нові тенденції зарубіжної, національної культури). До видів споживчої культури належать: індивідуальна (особистісна), соціально-групова й суспільна, кожна 3 яких характеризується своїми сутнісними характеристиками.

Невід’ємним складником професійної підготовки майбутнього вчителя $є$ формування в нього системи педагогічних компетентностей, із сукупності яких споживчу культуру вважаємо визначальною для становлення педагогічного професіоналізму. Для розвитку професійних здібностей, формування індивідуального творчого стилю i професійної позиції, оволодіння культурою спілкування i педагогічної діяльності необхідно переосмислити зміст і технології підготовки фахівців, обгрунтувати інноваційні методи і види навчання, зокрема- споживче навчання.

Отже, споживча культура вчителя - це сукупність матеріальних i духовних цінностей, знань, зразків і норм поведінки людей, соціально значущих і реалізованих у практичній діяльності.

Освіта $є$ одним з ефективних засобів формування споживчої культури, будучи невід'ємною частиною системи освіти і виховання особистості, і виконує унікальну функцію успішної соціалізації студентів.

Навчати майбутніх учителів споживчих знань ми пропонуємо в різних аспектах:

- через уведення спеціального курсу «Споживчі знання» (за рахунок варіативного складника навчального плану);

- через інтеграцію споживчих знань у зміст інших навчальних предметів;

- через упровадження споживчої освіти у зміст за межами вищого навчального закладу для проведення виховних заходів.

Перспективу подальших досліджень убачаємо в розробленні спеціальних завдань із формування споживчої культури майбутніх учителів технології.

\section{Література}

1. Большой социологический словарь (Collins). Том 1 (A-O) : [пер. с англ.] - М. : Вече, АСТ, 1999. - 355 с. 2. Лившиц Р. Потребление и потребительство / Р. Лившиц // Свободная мысль. - ХХІ. - 2001. - № 6. - С. 81-89. 3. Сорокина А. В. Особенности потребительского поведения студенческой молодежи / А. В. Сорокина // Соціологічні 
дослідження: зб. наук. пр. - Луганськ, 2006. - Вип. 6. - С. 90-97. 4. Сорокина А. В. Социологический анализ культуры потребления / А. В. Сорокина // Вісник Харківського університету імені В. Н. Каразіна. - 2005. - № 652. Соціологічні дослідження сучасного суспільства: методологія, теорія, методи. - С. 92-95.

Тетяна Герасимчук

\section{НОВІ МОЖЛИВОСТІ ІНФОРМАЦЙНИХ ТЕХНОЛОГІЙ У СИСТЕМІ ВИЩОЇ ПРОФЕСІЙНОЇ ОСВІТИ}

Герасимчук Т. В. Нові можливості інформаційних технологій у системі вищої професійної освіти.

У статті здійснено теоретичний аналіз навчальних можливостей інформаційних технологій у системі вищої професійної освіти, що дозволяють формувати професійну компетентність студентів автомобільно-дорожнього профілю; обгрунтовано умови формування й визначено структурні компоненти та функції професійної компетентності студентів автомобільно-дорожнього університету на основі електронних засобів навчання.

Ключові слова: інформаційні технології, інформаційна компетентність, функції професійної компетентності фахівця, компоненти професійної компетентності, умови формування професійної компетентності студентів автомобільно-дорожнього профілю.

Герасимчук Т. В. Новые возможности информационных технологий в системе высшего профессионального образования.

В статье осуществлен теоретический анализ учебных возможностей информационных технологий в системе высшего образования, позволяющие формировать профессиональную компетентность студентов автомобильно-дорожного профиля; обоснованы условия формирования и определены структурные компоненты и функции профессиональной компетентности студентов автомобильно-дорожного университета на основе электронных средств обучения.

Ключевые слова: информационные технологии, информационная компетентность, функции профессиональной компетентности специалиста, компоненты профессиональной компетентности, условия формирования профессиональной компетентности студентов автомобильно-дорожного профиля.

Gerasymchuk T. V. The new opportunities of information technology in the system of higher professional education.

This article provides theoretical analysis of learning opportunities of information technology in the system of higher education, allowing students of auto-road profile to form professional competence; the conditions of forming are proven and the structural components and functions of the professional competence of students of the Automobile and Highway University are identified and based on the e-learning .

Key words: information technology, informative competence, functions of the professional competence specialist, components of the professional competence, conditions of the professional competence of students of the Automobile and Highway University that are based on e-learning. 